Journal of History Culture and Art Research (ISSN: 2147-0626)

Tarih Kültür ve Sanat Araştırmaları Dergisi

Vol. 9, No. 4, December 2020

\title{
DOI: 10.7596/taksad.v9i4.2669
}

Citation: Surname, N. (2020). The Influence of Akhmet Baitursynov's Literary Publicistic Heritage on The Spiritual Development of Kazakh People at The Beginning of The XXth Century. Journal of History Culture and Art Research, 9(4), 286-297. doi:http://dx.doi.org/10.7596/taksad.v9i4.2669

\section{The Influence of Akhmet Baitursynov's Literary Publicistic Heritage on The Spiritual Development of Kazakh People at The Beginning of The XXth Century}

\author{
Nazira Dossanova ${ }^{1}$, Omirkhan Abdimanuly ${ }^{2}$, Enver Kapağan ${ }^{3}$
}

\begin{abstract}
The article examines multifaceted activities of an outstanding Kazakh poet and publicist of the early twentieth century, Akhmet Baitursynov, and his transformative role in the development of literature, as well as national press and the history of the liberation movement. Authors especially emphasize that the poet and enlightener A. Baitursynov, as a creative person, has completely devoted himself to serving the people and their struggle for independence. In the process of analyzing the poet's work, it was shown that his bright poetry and social activities, as in a mirror, reflected the history of his native people at a turning point in the social changes of the twentieth century.

Rich historical, literary and artistic material reveals the influence of Russian classical literature on the work of the Kazakh poet. The degree of artistic perception and adaptation techniques used by $A$. Baitursynov on I. A. Krylov's fables are revealed. The peculiar method and artistic skill of A. Baitursynov as a translator are considered in the given article. As an original fabulist, he uses words, expressions, proverbs and sayings that are close to and understandable to Kazakh people. He focuses on their critical and satirical orientation, which is aimed not to entertain, but to correct morals, teaching, and appeal to education. A. Baitursynov's special place in the history of the national press was identified as a talented publicist and bold editor of the Kazakh newspaper, which had a pronounced anti-colonial and enlightening orientation. His journalistic legacy was deeply investigated and systematically analyzed. The authors proved that it was in the field of the Kazakh press that the poet's powerful talent was most fully revealed, his role as the leader and inspirer of the liberation struggle of the Kazakh people was investigated.
\end{abstract}

Keywords: Kazakh, Kazakh literature, Akhmet Baitursynov, Kazakh poet, Linguistic.

\footnotetext{
${ }^{1}$ Department of Kazakh Literature and Theory of Literature Al-Farabi Kazakh National University 050040, 71 AlFarabi Ave., Almaty, Republic of Kazakhstan ORCID: https://orcid.org/0000-0002-4189-530 kaznu.nazi@gmail.com

${ }^{2}$ Department of Kazakh Literature and Theory of Literature Al-Farabi Kazakh National University 050040, 71 AlFarabi Ave., Almaty, Republic of Kazakhstan ORCID: https://orcid.org/0000-0001-9134-5132 abdimanuly@rambler.ru

${ }^{3}$ Assoc. Prof., Faculty of Education, Bolu Izzet Baysal University, ORCiD: 0000-0003-4647-1863 E-mail: enverkapan@hotmail.com.
} 


\section{Introduction}

The beginning of the XX century in the history of Kazakh literature can be called the Golden age. Historically, it coincides with the new rise of spiritual and artistic thought in Russia and the West. During this period, Shakarim Kudaiberdiev, Abai's successor, reached the heights of his creative heyday, and Akhmet Baitursynov, Mirzhakyp Dulatov, Zhusipbek Aimauytov, Sultanmakhmut Toraigyrov, Magzhan Zhumabayev declared themselves in full voice, creating highly artistic works of world significance.

The multifaceted work of a prominent poet, publicist, literary scholar, and linguist, Akhmet Baitursynov, is of high significance for the study of literature of the XX century. At the beginning of the twentieth century, he was one of the brightest leaders of the Kazakh national intelligentsia. His personal merit is the formation of his own platform for national independence. In his literary work and journalism, he first justified the scientific and philosophical, social content of the concepts of "freedom" and" equality", created an original concept of the free development of Kazakh society. The red thread in the work of Akhmet Baitursynov is the liberation idea of the Kazakh people. This idea is constantly heard in his talented poetry and publicistic works. All the poetry of A. Baitursynov is subordinated to educational activities, differs in spiritual and acute political orientation. Another aspect of this problem is the struggle against age-old ignorance, spiritual dormancy, lack of will and inaction. The poet actualizes urgent issues of culture, literature, and education in front of the public consciousness. A freedom fighter who calls for knowledge, he uses a peculiar poetic technique in his first works, translating the fables of the famous Russian poet I. A. Krylov.

A fable is one of the types of folk art that is understandable and accessible to everyone. As one of the types of allegory, it became an indispensable method for the poet, who was looking for a path to national liberation, to propagate his ideas in an era of strict censorship. Thus, through the poems of $\mathrm{I}$. A. Krylov, the Kazakh poet skillfully used the "Aesop" language.

The publication of the newspaper "Kazakh" is a bright milestone in the development of culture, literature and journalism of the Kazakh people. It became the first unofficial and most widely circulated Kazakh newspaper with a bold political voice. On its pages, the editor-in-chief A. Baitursynov spared no effort to fight for freedom and socio-cultural development of the nation. Thus, one of the manysided aspects of the poet's activity was journalism. His articles, written with a passionate pen of a fighter and publicist, served as a reference point for the advanced Kazakh intelligentsia. They answered the most pressing interests of the Kazakh people.

\section{Experiment}

A. Baitursynov's creative heritage consists of four main areas: poetry, translation, journalism and literary studies. His poetry, as we have emphasized above, was imbued with civic pathos. One of its characteristic features of the early twentieth century is the struggle for popular liberation. The evolution of the poet's views can be clearly seen in his works.

One of my favorite genres was fable. Fable is a genre of didactic literature. A short story in verse or prose with a directly formulated moral conclusion that gives the story an allegorical meaning. The collection "Forty fables" ("Kyryk mysal") by A. Baitursynov was reissued three times: in St. Petersburg (1909), in Orenburg (1913), in Kazan (1922).

The collection "Kyryk mysal" ("Forty fables") by A. Baitursynov consists of the poet's own works and translations of fables by I. A. Krylov. However, if Krylov's fables determine the main aesthetic laws of the genre, then $A$. Baitursynov uses these laws for a realistic representation of the Kazakh reality of the beginning of the XX century. Researchers believe that in 28 of them, the stories are borrowed from 
the French poet La Fontaine. But La Fontaine did not write a single fable of his own. And despite this, none of the researchers will say that these fables do not belong to Lafontaine. The fables of La Fontaine, Krylov and Baitursynov are a storehouse of age-old folk wisdom.

A significant event in the cultural life of the Kazakh society was the collection of poems by Akhmet Baitursynov "Masa" ("Mosquito"), published in Orenburg in 1911. This book captures a whole epoch in the history of the Kazakh people. None of A. Baitursynov's contemporaries managed to cover the real reality, the national life of the time of colossal social and historical upheavals of the early twentieth century in such a wide, diverse and highly artistic way. The set of characters created by the poet, representing literally all social layers of Kazakh society, the depth of penetration into the life of the people, the breadth of setting social and philosophical problems of the era make A. Baitursynov a truly national poet. His poetry gave rise to a new direction in Kazakh literature, which glorifies national unity and freedom.

Here the poet acts not just as a journalist, but as a mentor who has mastered all the subtleties of journalistic skill. For example, from the first issues of the newspaper "Kazakh" drew attention to the land issue. It led a determined struggle against its looting. It is not by chance that this newspaper paid special attention to enlightenment, since the situation of the people striving for science, knowledge, and education at that time was hopeless.

The newspaper "Kazakh" - the most popular publication of the early twentieth century-expressed the deep problems of the Kazakh society, raised the most acute problems of its time. Therefore, it had the highest circulation at that time - about 8 thousand copies, the most impressive volume of all periodicals of that time. For example, the magazine "Aikap" - the most popular publication-had a circulation of only 900 copies. In each of the 265 issues of the newspaper "Kazakh" there is a bright trace of the best authors who thought about the situation of the people and did a great job for them. The tribune of its era-the newspaper "Kazakh" - later became unpopular with the authorities: it is significant that it was closed 26 times.

Summing up, it should be said that the work of A. Baitursynov was a significant milestone in the development of all Kazakh literature and journalism of the beginning of the XX century.

\section{Results and discussion}

Akhmet Baitursynov's literary work begins with the translation of fables by the master of this genre, the classic of Russian literature I. A. Krylov. A fable is a poetic story-an incident in which the actors are usually animals, inanimate objects (Literary encyclopedia, 1987: 44). The purpose of the story is some moral truth, presented in action, and, consequently, awakening in us both feeling and imagination. It takes a real image in our eyes, leaves strong, long-lasting impressions (Belinsky, 1955: 66).

The collection "Kyryk mysal" ("Forty fables") by A. Baitursynov, released in 1909 in St. Petersburg, mainly consists of a translation of fables by I. A. Krylov. Classic of Kazakh literature M. O. Auezov in an article written in 1923, noted the following: "For the broad masses of the Kazakh people, the collection "Forty fables" was the first book that carries the revolutionary spirit. After that, A. Baitursynov became famous as a person who is sick with all his heart for the people"(Auezov, 1923: 17).

The theme of A. Baitursynov's fable works can be divided into two large groups. The first calls the people to knowledge, justice, and hard work based on humanity. It is dominated by morality and education. The second-calls on the people to unite, to fight for liberation.

The first group of the fables include: "the Swan, Pike and Cancer", "Donkey and Nightingale", "the owl and the Pussycat", "the old man and the Worker", the "Dog of friendship", "the Shepherd and the gnat", "the mirror and the Monkey", "Poor rich man", "pig under the oak" and other fables. In them, 
through negative images of animals, ignorance, braggadocio, and swagger are mocked. These expressive images recreated by the Kazakh poet are filled with folk wisdom, and the reality reflected in the fable is a mirror image of the human world.

The poet translates Krylov's fables, acting not just as a moralist, but as a virtuous poet. It exposes social vices, talks about the way to correct a person and society. Baitursynov's fables directly answer the question, what should a person be like? The poet considers satire to be one of the main means of education. He is convinced that laughter and irony are the main means of forming people's analytical consciousness. It is laughter, irony and sarcasm that will allow the Kazakh to see their own vices, understand the inhumane mores of society, opening ways to change themselves and society. The author consistently adheres to the classic rule: his fable consists of a story and an explanatory moral. And the moral of the fables is a separate conclusion. It looks like a moral conclusion. In addition, it reveals the author's position.

The Kazakh poet's fables are characterized by plot dynamics, detailed character development, and lively dialogues. The story turns out to be so individual and, at the same time, typical that the expressed "morality" is perceived by the reader as a real truth:

...Дүниеде түрлі-түрлы адамдар бар,

Жақсыда, арасында жамандар бар,

Ғылымды пайдаланып отырса да,

Сезбейтін сол пайдасын надандар бар. (Baitursynov, 1989: 79)

The are many different people in the world,

Some of them are good and some are bad.

There are ignoramuses who use science,

But do not know all its benefits

A. Baitursynov's fables contributed to the solution of General literary tasks set by time and the level of national consciousness of his historical epoch. Through them, the meaning of history is perceived, its role and conditionality in human activity, the ratio of spontaneous development, conscious will or arbitrariness of man in it. This not only reflected the level of understanding of new humanistic ideas, but also developed them, fought for them, contributing to the moral progress of all mankind.

The poetic originality of $A$. Baitursynov is contained in the second group of fables. His own style is particularly noticeable there. This includes fables that scourge usurpation and violence. These include "Wolf and Crane", "Wolf and Lamb", "pestilence of animals", "Wolf and cat", "Pied Sheep", etc.

Consideration of the content of one of them convincingly testifies to the abilities of the fabulist $A$. Baitursynov. Thus, the fable "the Wolf and the Lamb", which has a political significance, is written in a sharp satirical style.

This fable can be called a completely original work of the Kazakh poet, built on a similar plot. The translation of the Krylov original from 36 lines gets new content in 68 lines. The presence of these features is clearly visible at the beginning and end of the fable, as well as from the dialogue of the Wolf and the Lamb. Krylov's beginning is as follows:

Бұлаққа су ішуге келді қозы,

Жанында Серігі жоқ жалғыз өзі.

«Бөрі жоқ десең, шығар бөрік астынан»

Пәле мен қаза алыс па, келсе кезі. 
Ягненок в жаркий день зашел к ручью напиться,

И надобно же беде случиться,

Что около тех мест голодный рыскал Волк.

Ягненка видит он, на добычу стремится... (Krylov, 1945: 20)

A lamb approached the stream to drink one sultry day,

And things were destined to go wrong,

It chanced a hungry wolf came prowling round that way.

The wolf espies the lamb and marks him for his prey...

The third line at the beginning of A. Baitursynov's fable is replaced by a Kazakh proverb: "Bori zhok desen, shygar Borik astynan", which gives the text and the beginning of the entire verse a special flavor, a deep national content. If I. Krylov's ending is known from the very beginning, then $A$. Baitursynov gives the whole plot a logical conclusion at the end of the fable. The Wolf's accusations were made up in advance, and The lamb's justification borders on its real defeat. The lamb, until the last minute confident in his honesty and innocence, waiting for justice, having learned about his "main fault", obediently submits to fate:

Шошиды Қозы байқұс құлқын танып,

Құтылар білгенменен онан нағып?!... (Baitursynov, 1989: 63)

The Lamb Afraid of, knowing the temper of the wolf,

Sensing trouble, does not know how to escape?!

In the fable of A. Baitursynov, the usurpation inherent in the courts of tsarist Russia, which created lawlessness in Kazakhstan, is unmistakably visible. The main "fault" of the Kazakh people, who were under the rule of the Russian Empire, is similar to the "fault" and the fate of the Lamb. Alluding to this in the fable, the author shows by a colorful example that no justice can be expected from the colonization policy at all.

In General, the fables of the second group have a common idea. It is characterized by a deep content: empathizing with the plight of his own people, the poet portrays the main culprit of all the troubles. Therefore, it seeks to awaken the national consciousness. The main culprit of all the troubles is the colonial oppression of tsarist Russia. The development, flourishing and growth of the Kazakh nation is impossible without liberation from it.

From 197 fables of I. A. Krylov, A. Baitursynov chose and translated 38, giving them a single compositional structure. The book opens with the fable "Akku, Shortan ham Shayan" ("Swan, Pike and Cancer"), which calls for unity. Completes her fable "Malshi men Mas" ("the Shepherd and the gnat"), where the main idea is sound: "Wake up, Kazakh!»

A. Baitursynov's translations have become new and original creations of the Kazakh artistic reality. Covered with centuries-old folk wisdom, Krylov's fables in his poetry were spiritually transformed, receiving a fresh national meaning and sound. "Kyryk mysal "("Forty fables") by A. Baitursynov embodied all the beauty, power and grace of the native language. Revealing the psychology of the people, the essence of the Kazakh nation, the juiciness and richness of its language, he masterfully uses its laws. 
Speaking about the language of A. Baitursynov's fables, we can not say that they were widely distributed due to the use of capacious Kazakh Proverbs, sayings and winged expressions. These powerful means of the native language are given in the fables as examples. Sometimes they are translated directly, sometimes indirectly, in accordance with the structure of words and in order to preserve the meaning. Sometimes they are translated completely, giving a different structure and changing the position of words. Sometimes the poet uses peculiar phrases. It conveys a significant and deep meaning through a minimum of words, revealing the dignity and nobility of the wisdom of the Kazakh people. This is an example: "who could not distinguish the yellow of copper from pure gold", "Relatives: who is patron and who is the weapon", "Better an enemy than an ignorant friend"), "Wealth and happiness will not correct the temper", and other proverbs.

In an article dedicated to A. Baitursynov, M. O. Auezov noted: "The words spoken by Akhmet, the Kazakhs have not yet forgotten, the motives known in fables are not outdated. Until now, they, being strong in the melodies of the Kazakh steppe, together with the steppe free winds, spread everywhere» (Auezov, 1923: 17) . Emphasizing the immortality of the spirit of the ideas of citizenship, which became the banner of his poetry, M. O. Auezov emphasized its continuity. These motives are the main core in his own poems.

A significant event in the cultural life of the Kazakh society was the collection of poems by Akhmet Baitursynov "Masa" ("Mosqiuto"), published in Orenburg in 1911.

The ideological orientation of the poems is defined in the title itself. The poet's task is to awaken his people in a word, like a gnat that gives no rest:

Ұйқысын аз да болса бөлмес пе екен, Қоймастан құлағына ызыңдаса? (Baitursynov, 1989: 23)

Maybe he will Wake up from

the annoying buzzing in his ear

The ideological orientation of the poet's poems is the propaganda of enlightenment. The poet believes that only knowledge, culture, and poetry can somehow change the life of society. "Will you continue to live like this?» - the poet addresses his people. "Won't you Wake up, won't you get up?» (Poems "Happiness" ("Bak") and "Wish" ("Tilek Batam"). The interrelation of philosophical and aesthetic, artistic and spiritual principles characterizes the peculiarity of his work. The poet is characterized by a gravitation to the moral and spiritual origins of Eastern culture, to the ideological and aesthetic search for Russian classical literature and Kazakh folklore. All the poetry of A. Baitursynov is characterized by a deep spiritual and acute political orientation. Surprisingly, the poet's lyrics combine the ideas of humanism with the irreconcilable political struggle for the awakening of the national consciousness of the Kazakh people.

His work captures an entire epoch of native history. The set of characters created by the poet, representing literally all social layers of Kazakh society, the depth of penetration into the life of the people, the breadth of setting social and philosophical problems of the era make A. Baitursynov a truly national poet.

What prompted A. Baitursynov to become a poet? What powerful force moved his genius mind, the power of talent for a high goal? Considering himself the son of the people, he grew up and hardened in the struggle for their national freedom and independence. In this struggle, the sharpest weapon was poetry, the closest and most understandable to the people. He is writing: 
Мен жазған кеңес,

Мақтаныш емес,

Ат шығармақ, ақындық...

(«Жауап хаттан») - (Baitursynov, 1989: 41)

The councils have written me

no radiance,

that lam a famous poet («Answering Letter»)

The poet puts the idea of freedom above all, through his poems he seeks to convey to the people the most intimate thoughts and aspirations. He gives his poetry a sharp socio-political sound. This is evident in the verses: "Orarily Alsina" ("To the city Karkaraly"), "Zhauap Hatton" ("Response letter"), the "Dosym hat" ("Letter to friend"), "Jaua tsken sozi" ("Words of the person who is the enemy"), "Bak" ("Happiness") and other poems.

One of the first poems that started this cycle is "ANAMA hat"("Letter to the mother"). The time of writing this poem is precisely indicated By M. Dulatov: "In a letter to my mother", written in 1909 from Semipalatinsk prison... The poem, which has escaped from the hidden depths of the heart, deeply reveals a soul full of lyricism and hope. Dedicating it to the dearest person - the mother, and bowing his head before her, he realizes that he is the son of the people, whose service is the highest duty" (Dulatov, 1922: 19)

The desire to fight for the liberation of the people from colonial oppression, the desire to help them realize themselves - this is the spiritual and romantic direction of the poet's work. The blame for ignorance-the tragedy of the Kazakh nation - lies entirely on the colonial policy of tsarist Russia:

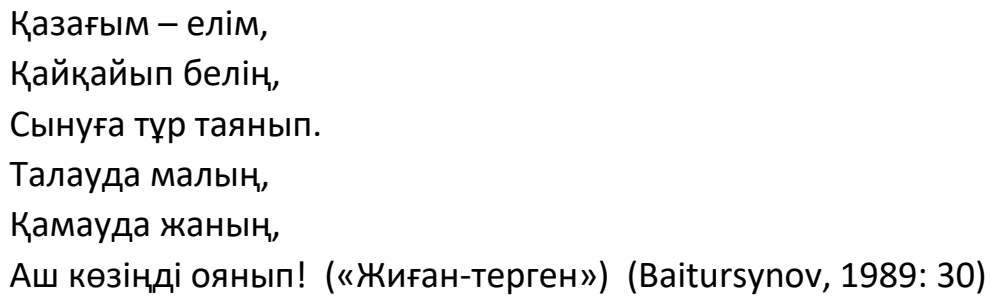

Kazakhs are my people, Your back is bent, It is ready to break, Your people Are Under arrest, Open your eyes and Wake up. («Gathered»)

After the poem "Letter to mother", another poem - "N. K. khanymga" ("to Mrs. N. K.") became one of the most significant. It revealed the depth of his thoughts. Addressed to young people, this poem explains the purpose and difficulties of the chosen path, as well as reveals the deep philosophical meaning of the life of a fighter for national happiness.

Accusations and persecutions of the poet are intertwined with his difficult fate, with thoughts about the essence of human dignity, the purpose and meaning of freedom. In the end, they lead him to think about life and death, about the present and the future: 
Тән көмілер, көмілмес еткен ісім,

Ойлайтұғын мен емес - бір күнгісін,

Жұрт ұқпаса, ұқпасын жабықпаймын,

Ел - бүгіншіл, менікі - ертеңгі үшін. (Baitursynov, 2003: 198)

The body will be buried, but not my business,

I don't think only about today -

if people don't understand, well,

let them not understand - I won't be offended,

They live for today, and my business is for the future

The poet sees the victory of the present, which is what his whole life is dedicated to, in the future. In the poem "To N. K. Khanym" we can easily recognize the image of a fighter, a hero of a new era, ready to sacrifice his life for the sake of tomorrow's happiness of his people.

A. Baitursynov's poetry is not just a celebration of freedom, bordering on national grief, but also a true understanding of the origins of the future and pointing the way to it. Kazakh poets, who had felt the tragedy of the people before him, saw their liberation only in enlightenment. They did not yet know the right path, but A. Baitursynov showed not only the way to the cherished goal, but also urged them to follow it. Enlightenment in his poetry led to the awakening of national consciousness, and the awakening - to identify the main culprit of the tragedy and to "beautiful impulses" that open the road to freedom. This is the path in poetry trodden by A. Baitursynov.

About the poet's special place in Kazakh literature his contemporary M. Dulatov said the following: "He sings in simple and understandable Kyrgyz (ka-zakhsky - OA) language about freedom, about the nation - about the oppressed and backward Kazakh nation, calling it to enlightenment, to work and liberation from age-old hibernation and awakening in every Kazakh a sense of citizenship. A. Baitursynov's poems take the first place in the Kyrgyz (Kazakh - OA) literature for their external beauty, internal content, lightness and uniformity» (Dulatov, 1922: 17).

Summing up, it should be said that the work of A. Baitursynov became a milestone in the development of all Kazakh literature of the beginning of the XX century. He laid the foundations of liberation and democratic poetry in the Kazakh literature of the early twentieth century. Therefore, we should consider the creative legacy of A. Baitursynov as a "spiritual leader» (Auezov, 1923:100), as the undisputed leader of the Kazakh people.

Until 1988, researchers of the history of journalism ignored the newspaper of A. Baitursynov "Kazakh", and if they remembered it, it was only for denigration, in order to argue their own ideologized thoughts.

The Kazakh intelligentsia entered the political arena in 1905. This was most likely due to the Tsar's Manifesto of October 17, 1905. In the first paragraph of this document were the words: "To grant to the population the unshakable foundations of civil liberty on the basis of the actual inviolability of the person, freedom of conscience, speech, Assembly and unions." They opened up great prospects for the active activity of the advanced Kazakh intelligentsia.

This is evidenced by its other bright leader A.Bokeikhanov: "The unforgettable days of freedom have come. The Manifesto of October 17 was translated into the Kyrgyz language... it was printed in the Akmola regional printing house and distributed throughout the Kyrgyz steppe. Kirghiz people living in cities were elated when they received telegrams summarizing the Manifesto. Public meetings were held for the first time in the steppe and steppe cities. In the cities, the Kirghiz joined the exultant 
intelligentsia, who spoke of the equality of all, of freedom of conscience, and of the power of the people" (Bukeikhanov, 1985: 56).

A prominent statesman and political figure of 20-30 years T. Ryskulov writes about the activities of the Kazakh intelligentsia of this period: "in the 90s, the role of leader and representative of national interests begins to play the nascent Kazakh national intelligentsia. ...This movement (the nationalist movement of the intelligentsia), led by A. Bokeikhanov, A. Baitursynov and others, grouped around the newspaper "Kazakh", defeats the pan-Islamic group of intellectuals, United around the magazine"Aikap". ...it marks the beginning of the design of the literary Kazakh language, etc. While preparing an Alliance of the Kazakh elite with the liberal Russian bourgeoisie, this intelligentsia at the same time speaks out against the Russification policy of tsardom, land grabs and a number of other shortcomings» (Ryskulov, 1984: 160).

This is confirmed by the famous historian of the 30s of the XX century S. Asfendiyarov: "The Kazakh intelligentsia is divided into two main groups. One part, grouped around the magazine "Aykap" (M. Seralin, D. Seidalin), stood on the pan-Turkist position of the bloc with the Tatar bourgeoisie, for the unification of all the Turks. She put forward the requirements of settling the Kazakh population and stood for the development of Tatar new-fashioned schools. The other was grouped around the newspaper "Kazakh", which began publication in 1913. (Bukeikhanov, Baitursynov, Dulatov, etc.). This part required the development of the Kazakh language, considering that "a block with Tatars" would lead to assimilation. This group was also against settling, believing that a sharp change in the Kazakh economic life will be extremely harmful and painful for the Kazakh economy" (Asfendiyarov, 1935: 225), - at the same time, and notes that "the Second group, more numerous...".

From 1905 to the revolution of 1917, the leaders of the Kazakh intelligentsia held various events: meetings and congresses. The collection "the Press and the national movement among Russian Muslims before 1920", published in the series" Economic and sociological Sciences " of the Sorbonne University, contains the following facts: "at the end of 1905, the first official meetings of Kazakhs were held in Orenburg, the Congress of intellectuals of the West was chaired by A. Bukeikhanov, in Verny (the future Alma-ATA), the Congress of intellectuals of the East was chaired by Ahmed Baitursun, a prominent writer and philologist" (Bennigsen, 1920: 8). One of the main issues discussed at these congresses was the publication of Newspapers and magazines in their native language."

In 1910 Alikhan Bukeikhanov wrote: "There are no Newspapers in the Kyrgyz (Kazakh - OA) language yet, just as the Kirghiz (Kazakhs-OA) do not yet have their own printing house" ("Kazakh" (newspaper), 1913: 51).

Finally, the long-awaited day came, and the newspaper "Kazakh" was published on February 2, 1913. It was published until September 16, 1918 in the city of Orenburg. Its editor was A. Baitursynov, and its publisher was Mustafa Orazayev. The time of the newspaper "Kazakh" falls on the events when the Kazakh population experienced the upheavals of the 1905 revolution, when, having understood the true causes of the people's illness, the intelligentsia awakened the nation, gathering its forces together, speaking out against tsardom, when it decided to move from words to deeds.

The purpose of the newspaper is to show Kazakhs living in poverty and darkness the right path (Dulatov, 1922: 21) . In their address to readers, the publishers explain its tasks: "to serve for the benefit of the people, to guide the spread of science and art, to acquaint with the life of other peoples. To do this and give comprehensive news about the laws of the administration, the work of The state Duma and the State Council, place your own and incoming news, write about the situation of Kazakhs in the past and present; consult about life, trade, profession, crops, livestock; show the way of learning 
in schools, madrassas, a school to teach the art, language and literature; to write about the treatment of people and animals» ("Kazakh" (newspaper), 1913: 51).

The high goal of the newspaper was to turn it into a center for educating literate people. The basis of many accusations against it, which allegedly had the "correct orientation" only before the February revolution of 1917, is that it was the reason for the formation of the Alash party. Putting her active struggle for freedom and the future of her own people into oblivion is tantamount to burying her in history.

In articles of A. Baitursynov "Kazakh Jany" ("the Kazakhs"), "Asia kereg" ("the needs of the Kazakh"), "garisy Bilim" ("knowledge Competition"), "school character" ("schools"), "Bastus Mektep" ("Elementary school"), "BL Zamani Soisy" ("the War this time"), "Law gobbini bandanas" ("Report on the draft law"), "Kazakh m Duma (the Duma and the Kazakhs"). "Kazak zherin Alu Turaly Nizam", " Kazakka Ashyk hat "("open letter to the Kazakhs")," Tagy da people's court of khakynda "("Once again about the people's court") and others describe the economy and economy of the Kazakhs, the political situation of the time and cultural enlightenment. The newspaper, sensitive to the essence of social and political changes, sought to give them a principled assessment, while maintaining impartiality. The newspaper's desire to cover all aspects of the life of the people was based on the broad tasks set by it.

The beginning of A. Baitursynov's journalism is closely connected with the newspaper"Kazakh". Here is how the founder of the Kazakh Soviet literature S. Seifullin writes about it: "Since 1905, among the Kyrgyz (Kazakh - OA) intelligentsia... there was a spread of the revolutionary idea, i.e..... the idea of national equality and liberation. The inspirers of the awakening young Kyrgyz intelligentsia were prominent at that time "revolutionary" cadets, publicists Bokeikhanov, Dulatov and Baitursynov " (Seifullin, 1920: 13).

A. Baitursynov's thoughts about freedom are true and sharp. These ideas are priceless because they reveal the essence of the colonial policy of tsarist Russia. They are closely related to the threat to the Kazakh people in matters of land and self-government. The newspaper had a well-thought-out concept on many issues, including land, education, and power. It is almost impossible to fully cover, study and analyze all the problems raised by the newspaper "Kazakh", but it is possible to determine its historical role and the activities of its editor-in-chief A. Baitursynov in the circle of three main issues.

The question of land - "small - janimine sadasi, zhanym - alumni sadasi" (cattle (wealth) will donate in the name of the soul, and the soul will sacrifice for honor») the most important question for Kazakhs. At the beginning of the XX century. There was a process of intensive capture by Russian settlers of the most fertile lands of the Kazakh people. By the time the first issues of the Kazakh newspaper were published, this process had intensified. The tsarist government purposefully led the Kazakh people to tragedy. Therefore, the environment of the newspaper "Kazakh" could not help but interfere in such a vital issue. This is what the editor of the newspaper wrote about it. Baitursynov: "the most important issue for Kazakhs is the question of land. This is a matter of life and death. A mistake in this issue, orientation on the wrong path - and all responsibility for 5 million Kazakhs will fall on our shoulders. Therefore, it is best to openly tell the truth to the Kazakhs, advise them, without misleading others" ("Kazakh" (newspaper), 1914: 14 ). This truth was told from the pages of the newspaper "Kazakh" by its active authors A. Baitursynov, A. Bukeikhanov, M. Dulatov.

It is no accident that the newspaper "Kazakh" paid special attention to enlightenment, since the position of the people striving for science, knowledge, and education, unfortunately, depended on primary schools. There is no doubt that many problems had to be solved to improve it. Of course, at that time there were few Kazakhs who graduated from secondary and higher education institutions. And in General, with the increase in the number of schools and their correct orientation, the awakening 
of national consciousness and the increase in literate youth was undoubtedly the core of all problems. It is also true that those who graduated from primary school could participate in the dissemination of knowledge among the people.

Numerous articles by A. Baitursynov in the newspaper "Kazakh" about teaching in the native language are the origins of many of his linguistic works and the textbook"Oku kuraldary". His articles are imbued with the idea of teaching the Kazakh language and literature. This idea of his was taken up and developed by his supporters. M. Dulatov in his article "Til kuraly" writes: "No one will dispute that the newspaper "Kazakh" writes in Kazakh and raises issues of the Kazakh language. Who does it depend on? Of course, from the publisher. The magazine "Aykap", which has been published for four years, and the newspaper "Kazakhstan", which has ceased publication, did not pay attention to this" ("Kazakh" (newspaper), 1915: 15).

Criticism of the policy of the tsarist government is, of course, not only in the above-mentioned issues. But through them there was opposition to the political structure of the system. This is evident in the articles on power, where, noting the best qualities and sides of Kazakh traditions and customs, it is proposed to use laws that are literate and adapted to the life of Kazakhs. Both A. Baitursynov and A. Bukeikhanov spoke about this most fully in the newspaper. They opposed the solution of issues of power and governance through customs and Sharia, but they supported the solution of these issues with regard to national interests and on the basis of civil laws. Many articles by A. Bukeikhanov have been published on this topic. A. Baitursynov's article "Report on the draft law" on this issue is valuable precisely because it exposes the usurpation of colonial policy. For their views, the newspaper "Kazakh" was even fined 3 thousand rubles. But open indignation and hot disputes of the Kazakh intelligentsia led by A. Baitursynov reached the Senate, and there are national leaders proved the correctness of his opinion. This clearly shows that the newspaper "Kazakh" was a staunch and genuine fighter for national liberation and spiritual revival of the nation.

\section{Conclusion}

In the XX century, the development of the Kazakh national and spiritual revival and self-consciousness followed the path of progress. Many of the worthy figures of Alash put their strength and talent to solve the most important and fateful problems of the nation. Through the artistic works and journalistic writings they opened the eyes of the people, in a timely manner answering the most pressing, topical issues of the Kazakh life.

We must remember the historical role of $A$. Baitursynov at the beginning of the XX century, the leader of the national intelligentsia, who profoundly mastered various aspects of art and science, an indomitable fighter on the path of political enlightenment and spiritual liberation of the people.

Having laid the foundations of a new direction in the literature of the early twentieth century, he expressed in his work the age-old aspirations and dreams of the Kazakh people, pointed out the right path to freedom. Thus, he discovered the origins of the spiritual and Patriotic current in Kazakh literature.

A. Baitursynov, an ardent fighter for the freedom of the Kazakh people, rightfully took an honorable place in the national history. Therefore, we tried to consider his work through the prism of the historical life of the Kazakh nation. It was important for us to trace the evolution of the views of this outstanding personality of the early twentieth century. We also comprehensively revealed the outstanding literary and publicistic gifts and social activities of A. Baitursynov, a poet and journalist.

Mainly, we have shown the beneficial and powerful influence of the literary and publicistic heritage of Akhmet Baitursynov on the spiritual development of the Kazakh nation in the early twentieth century. 


\section{References}

Literary encyclopedia (1987). - Moscow: Soviet encyclopedia. 751p.

Belinsky, Vissarion (1955). Complete works: journalism/ Moscow: Akad Publishing house. Science of the USSR in $9 \mathrm{t}-\mathrm{x}, \mathrm{Vol} .7-438 \mathrm{p}$.

Auezov, Mukhtar (1923). ("Fannin of the ELU international toyi») "To the anniversary of Akhmet Baitursynov". AKZhol newspaper, February 4. 465 p.

Baitursynov, Akhmet (1989). (Ciarmatori: Leder, audiometry, siteuser) Works: poems, translations, research. - Almaty: Zhazushy. 320 p.

Krylov I.A. Complete works. Moscow: State publishing house of art.lit., 1945-1946. Vol. 3, p. 619

Dulatov, Mirzhakip (1922). Ahmet Baitursynov. Proceedings of the society for the study of the Kyrgyz region. III issue-Petersburg: 17-27 p.

Baitursynov, Akhmet (2003). (Gebiet tunity. Siteuser me later) Adebiet canadys. research and poems. - Alma-ATA: Atamura. 208 p.

Auezov, Mukhtar (1923). (Konyr) Kazakh debien modern door) "the Modern period of Kazakh literature" № 4,5 the magazine "Sholpan", p. 100-122

Bukeikhanov, Alikhan (1985). Kirghiz // The Kazakhs about the Russians until 1917. Society for the study of Central Asia. Oxford: - 93 p.

Ryskulov, Turar (1984). Contemporary Kazakhstan. Selected works. - Almaty: Kazakhstan, 150 p.

Asfendiyarov, Sanjar (1935). History of Kazakhstan (Since ancient times), Vol. I. - Alma-ATA-Moscow, $261 \mathrm{p}$.

Bennigsen, Alexander, Of Shantal, Lemerise (1964). Calcia. Kazakh-Kyrgyz press. // Press and national movement among the Muslims of Russia before 1920-Paris, - 144-155 p.

"Kazakh" (newspaper) (1913). Orenburg. S. 3. 51-55

Seifullin, Saken (1920). (Manap Shamil) About the Kazakh intelligentsia. "Life of nationalities", November 25. 13-15

"Kazakh" (newspaper) (1914). Orenburg. S. 48. 14-20

"Kazakh" (newspaper) (1915). Orenburg. S. 93. 15-18 